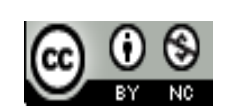

Jurnal Pendidikan Bahasa dan Sastra Indonesia is licensed under

$\underline{\text { A Creative Commons Attribution-Non Commercial 4.0 International License }}$

\title{
The Use of Multisensorial Media in Learning Writing Narration Based on Balance of Brain Functions in Elementary Schools
}

\author{
Ririen Wardiani ${ }^{1)}$, Sarwiji Suwandi ${ }^{2)}$, Andayani ${ }^{3)}$, Budiyono ${ }^{4)}$ \\ 1) Program Studi Pendidikan Bahasa Indonesia, Universitas Sebelas Maret, Indonesia \\ 2) Program Studi Pendidikan Bahasa Indonesia, Universitas Sebelas Maret, Indonesia \\ E-mail: sarwijiswan@yahoo.com \\ 3) Program Studi Pendidikan Bahasa Indonesia, Universitas Sebelas Maret, Indonesia \\ E-mail: $\underline{\text { bu_anda09@yahoo.co.id }}$ \\ 4) Program Studi Pendidikan Matematika, Universitas Sebelas Maret, Indonesia \\ E-mail: budiyono53@yahoo.com
}

\begin{abstract}
The purpose of this study is to describe the application of the use of multisensory media in learning to write narratives based on balancing brain function. The research method used is descriptive method with a qualitative approach. Place of research in elementary schools in Ponorogo. Subjects in the study were teachers and elementary school students in grade IV. Data collection techniques are direct observation techniques, interview techniques, and tests. The instruments of data collection are observation guides, interview guides, and test questions. The data analysis technique uses mastery learning guidelines. The results showed that the use of multisensory media in the form of media images, concrete objects, and film media can be used to ignite emotions as a basis for the initial search and development of ideas. The use of picture media can produce students categorically mastery as many as 30 students, the use of concrete media objects 59 students, and the use of film media as many as 63 of the 72 students studied. The use of multisensory media is very important in implementing learning based on balancing brain function.
\end{abstract}

Keywords: multisensory media; writing narration; learning based on balancing brain function

\section{INTRODUCTION}

Referring to education in the 21 st century era, the ability to read and write is needed. On the other hand the ability to write shows unsatisfactory results. Suparno and Yunus explained based on the results of research conducted that the aspects of language learning that were most disliked by students and teachers were writing or composing. The reason is as stated by Graves (in Suparno and Yunus, 2008:14) someone is reluctant to write because they do not know what to write and feel not gifted to write. Writing dislike is inseparable from the influence of the family and community environment, as well as the experience of learning to write in schools that lack motivation and stimulate interest. Research conducted by Hartati et al. (2013:47) explains some of the difficulties students have in writing learning such as difficulty in choosing a title, difficulty in developing character, difficulty in developing a background, difficulty in developing a scenario (at the beginning, in the middle, and at the end of the story), it's difficult to introduce new vocabulary, it's difficult to arrange paragraphs, it's difficult to review stories.

Based on the explanation above, it is necessary to develop innovations in writing learning. Some of the studies conducted by previous researchers include Black J. (2014:21). The results of his research recommend that teachers are expected to vary the use of various learning styles and compile childcentered video media making. Research Yamac A. \& Mustofa U (2016:59-86) describes the need for digital media in storytelling that is expected to influence writing skills among low economic groups and high economic circles.

The concept of writing according to Rivers's view (1981:294) is to convey information or original expression of ideas in sequential ways in new languages. In line with Rivers's view, Graham et.al. (2012:7) states that writing is a communication of thoughts and ideas. Writing is a complex skill, besides being a cognitive activity, writing requires provision of knowledge about what will be written, for whom the writing is written, and must be skilled and flexible to communicate it into a writing. A concise view of the stages of 
the writing process revealed by Tompkins (2008:7) presents five stages, namely: 1) pramenulis, 2) drafting, 3) revising, 4) editing, and 5) publication / (sharing).

This study describes the use of multisensory media in writing learning based on balancing brain function. The use of this media is used to ignite emotions. Through the use of multisensory media can stimulate and call the memory that has been stored. Calling memory is lighted through the media used.

Learning based on balancing brain function is learning based on the natural brain at work. There are several factors that influence brain-based learning, namely attention, pattern and context, emotions, motivation, in addition to two other important things in the learning process, namely (1) memory functions and (2) association and execution functions. (Weiss, 2000:24) Memory is very important in developing creativity. This is supported by the opinion of Guenther (Given, 2004) that human memory is more designed to anticipate the future than to perpetuate the past. Brain-friendly learning according to Hanson $(2009: 2)$ must pay attention to 4 main principles to apply in classroom learning. The four principles are Safety, Respect, Novelty, and Memory. Safety is that classrooms must be safe, capable of raising awareness and trust before learning. Respect is children will develop well if the combination of their unique learning styles is valued and gets support. Novelty is a challenging, interesting, and new activity that gives rise to positive emotional conditions so that the conditions of learning can lead to bonding or participation and pure learning opportunities. Memory is entering and building on existing memory which influences pure learning and can maintain new memory. Given (2007:371-376) argues that brain-based learning has five systems: 1) emotional learning systems; 2) social learning system; 3) cognitive learning systems; 4) physical learning system; 5) reflective learning system. Based on several opinions above it can be concluded that in brain function based learning includes three things, namely: initiating the learning process is recommended for emotional involvement. This emotional involvement is motivated by the feeling of students who are comfortable, happy. Teachers should be able to arouse or ignite the emotions of students to get ideas in writing. Learning as much as possible is fun. Besides that learning must have the principle of safety which is to have safe classrooms that are able to bring out a sense of caring and mutual trust in the beginning of learning.

When learning takes place, the need to integrate the concepts of visual, auditory and kinesthetic learning, besides learning should pay attention to the following five things: (a) teaching visual, verbal, auditory concepts equally; (b) using visual aids that are balanced by placing diagrams vertically which shows the stages or structure; (c) discuss logically balanced with intuitive power; (d) consider the interpretation of the left brain that thinks through words literally which is balanced by the interpretation of the right brain through intonation, body language and content; (e) designing activities and assessments for a variety of different learning styles. When the learning process takes place it is also supported by the existence of a social learning system that regulates interaction and communication with oneself and others and cognitive learning systems that interpret, store, and elicit information, intentionally focus on information, and deliberately provide input to all other systems . Coupled with the attitude of respect for teachers to their students. Children will develop well when a combination of their unique learning styles is valued and supported.

The closing activity in the brain function-based learning process requires the existence of a constant reflective learning system that acts as a monitor for individuals. Also needed memory that can enter and build on existing memory has an effect on pure learning and can maintain new memory. This is expected by students to reap the benefits in learning contextually.

The way to think of the right brain is random, irregular, intuitive, and holistic. How to think in accordance with ways to find out which are nonverbal, such as feelings and emotions, awareness that pleases the feeling (feeling the presence of an object or person), spatial awareness, recognition of shapes and patterns, music, art, color sensitivity, creativity and visualization. The two hemispheres of the brain are important. People who use these two hemispheres also tend to be balanced in every aspect of their lives. Learning feels very easy for them because they have the choice to use the parts of the brain needed in every job they do. Most communication is expressed in verbal or written form, both of which are left brain specialties. The fields of education, business, and science tend to the left brain. If someone in the left brain category and does not make a certain effort to include some right brain activity will cause imbalance. The resulting imbalance can cause stress and also poor mental and physical health. To balance the tendency towards the left brain, music and aesthetics need to be included in the learning experience and provide positive feedback. All of that has a positive effect on yourself. Positive emotions lead to brain power that leads to success, which leads to higher self-respect, which leads to positive emotions - meetings that elevate to higher and higher ones (DePorter \& Hernacki, 2009:38).

The principle of balancing brain-based learning is easily explained by Sousa (2012:232), namely: 1) Efficient class organization; 2) Relevant bulletin boards; 3) Clean the boardtulis; 4) Using a multisensory approach; 5) Using metaphor; 6) Encourage accuracy and regularity; 7) Stimulation of logical thinking; 8) Give students several choices; 9) Use a visual display; 10) Help students make connections; 11) Encourage direct activity; 12) Give opportunities for student and student interaction; 13) Teaching aims at transfer; 14) Include practical learning.

Based on the writing process and the concept of learning based on balancing brain function, the following is explained about syntagmatics. This syntagmatic in the form of concrete steps carried out in carrying out learning based on balancing brain functions, namely (a) Appealing to Emotions, this phase provides stimuli for the discovery of ideas with class conditioning and emotions of students. Emotional activity can be done including presenting pictures, concrete objects or films, in learning. This activity is expected to stimulate students to call on experience in developing writing. (b) 
Clustering, this phase is a continuation of the reflection of ideas by grouping ideas in the form of clusters in the form of bulkah (box and arrow circles) or in other forms that connect the activities of the right and left brain with symbols, signs, and colors. This activity is the dominance of the right brain. Writing ideas are expressed in grouped or clustered words. (c) Expression, this phase is the draft writing phase based on the clustering process. Pantikan and klustering provide input for this writing stage. The brain that is more dominant at this stage is the left brain. (d) Edit, this phase is a phase that is dominated by the left brain that regulates it, the right brain remains with its intuitive power that is able to influence editing activities, namely editing, evaluating. Posts that have been made can be edited with various techniques. The peerage technique, analyzed together, and corrected directly by the teacher. (e) Reflection, is a stage which is a strengthening activity so that it always remembers what has been done, and will repeat it pleasantly. This activity begins with the teacher by analyzing the results of writing narratives of students who have been edited. Teachers and students improve which ones are lacking and which ones need to be added. This stage of activities is expected to generate selfawareness about the results of subsequent writings. (f) Display, this phase is a disclosure of results. Like this business is the final effort of all processes that go through. This display stage is a publication activity that can be carried out in various ways, namely giving an art effect.

Writing skills in this study focused on narrative writing skills. This narrative genre is chosen because writing narratives is the most basic skill that must be mastered by children. This is in accordance with Martin M research. (2010: 34). Martin explained that the ability to write narratives is the first step needed to teach the writing process for students. Writing narratives is a basic skill in writing in the form of personal writing. The skills developed in writing personal narratives are the ability to organize, use spelling, choice of words, and the ability to edit or revise. This study uses three types of emotional lighters, namely using media images, using concrete media, and using film media. Practically this study will describe how the application of multisensory media in writing learning is based on balancing brain function in elementary schools.

\section{METHODOLOGY}

The research method used is descriptive method with a qualitative approach. This study describes qualitatively focusing on the presentation of the results of the ability to write student narratives which are triggered using multisensory media such as media images, concrete objects, and films. This research was conducted in three elementary schools namely SD Maarif, SDN 2 Brotonegaran and SD Santa Maria in Ponorogo Regency. The subjects of this study were the fourth grade students totaling 72 students. Data collection techniques are direct observation techniques, interview techniques, and tests. Data collection tool namely observation guide, interview guide, and test questions. Data analysis techniques use the principle of mastery learning. Students are said to be able to write narratives if they personally obtain a minimum questionnaire score of 75 . The aspect assessed in writing ability is the maximum scale of each component. The assessment component refers to the opinion of Nurgiyantoro (2012: 439-440), namely: 1) the contents of the ideas put forward, 2) organizational content, 3) grammar, (4) style, choice of structure, and vocabulary, and 5) spelling and order write down. Assessment of each aspect based on the maximum value scale. Aspects of content maximal value 30 , organization of contents, 20 , textbooks 25 , use of vocabulary 20, spelling 5. Maximum score of 100.

\section{FINDING AND DISCUSSION}

The implementation of this study was carried out for 3 months in 2017. Each school carried out 3x learning meetings with an allocation of 70 minutes each week. The first meeting of learning was lighted using picture media, the second meeting using concrete objects in the form of bags and sandals, the meeting of the three media used to ignite emotions was film media. The results of the study using multisensory media in learning to write narratives based on balancing brain function are shown in table 1 below.

TABLE I

DISTRIBUTION OF SCORES WRITING ABILITY OF NARRATION BASED ON BALANCE OF BRAIN FUNCTIONS USING MULTIINDRAWI MEDIA

\begin{tabular}{ccllll}
\hline No & Interval & $\begin{array}{c}\text { Session I / } \\
\text { Picture }\end{array}$ & $\begin{array}{c}\text { Session II / } \\
\text { Concrete } \\
\text { objects }\end{array}$ & $\begin{array}{c}\text { Session } \\
\text { III/film }\end{array}$ \\
\hline 1 & $35-44$ & 1 & - & - \\
2 & $45-54$ & 1 & - & - \\
3 & $55-64$ & 13 & 6 & 1 \\
4 & $65-74$ & 27 & 17 & 8 \\
5 & $75-84$ & 30 & 47 & 49 \\
6 & $85-94$ & - & 2 & 14 \\
7 & $95-100$ & - & - & -
\end{tabular}

Based on the table above we can know that the image media used is two-dimensional media in the form of umbrellas and bags. The use of this image media produces students who are categorized as completing as many as 30 people from the remaining 72 studied. The use of concrete media that is carried in the classroom is in the form of sandals and bags that can be seen, held, used to provide an opportunity to call on the experience of students in writing. This is evident in the second meeting of students who were able to write narratives as many as 49 people from 72 students studied. The third meeting using film media with the same theme turned out to have brought students to satisfying abilities. Students are declared mastery as many as 63 out of 72 give good results.

Students respond more and show good results by using media concrete objects and film media when compared with using media images. This shows that the media that are sensory as an emotion-lightening media in composing narratives have an important role. The success of narrative 
writing learning will be achieved, one of which is influenced by the choice of apperception in the form of emotional lighters involving activities based on balanced right and left brain functions. Why can concrete objects and film media be accepted by students? This is in Piaget's view (in Schunk, 2012:331) there are four stages of cognitive development, a) sensoricotor stages (birth to 2 years), b) Pre-operational stages ( 2 to 7 years), c) Concrete Operational stages (7 up to 11 years), d) formal operational stages (11 years to adulthood). From his research, Piget concluded that cognitive development of children goes through a fixed sequence. The pattern of operation that can be done by children can be said as a level or stage. Each stage is determined by how children see their world

The results of the study when viewed from the aspects of writing are shown in Figure I

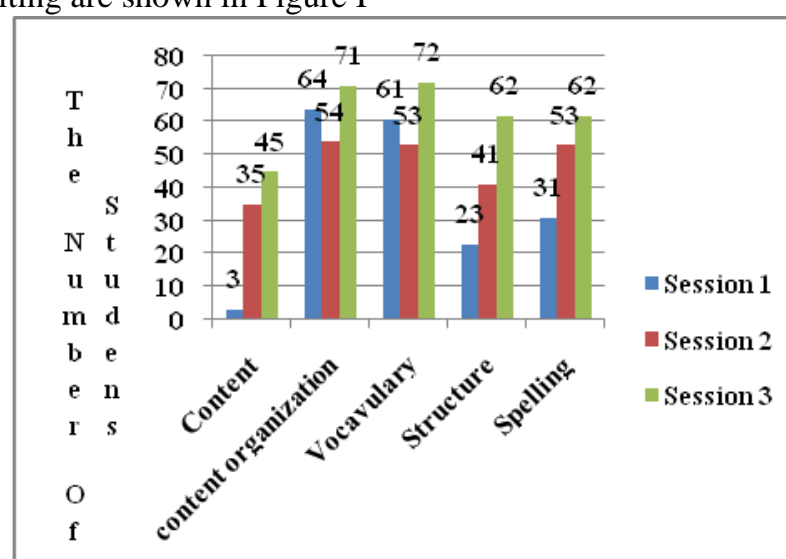

Writing a spect

Fig 1: Ability to Write Narratives Using the Brain Function Balancing Model

Based on the aspects assessed in the first meeting, 3 of 72 students met good criteria in the aspect of content, 64 students met good criteria in content organization, 61 students in vocabulary, 23 students in grammar and 31 students in spelling. Of the five aspects, the lowest level of achievement is the content of the ideas expressed, the contents of less creative ideas. This is illustrated in Figure 1.

The results obtained in the second meeting, 35 of 72 students met good criteria in the aspect of content, 54 students met good criteria in content organization, 53 students in vocabulary, 41 students in grammar and 53 students in spelling. This is supported by interviews that students feel that concrete objects and groupings related to the storyline help them. This is illustrated in Figure 1.

The results of the third meeting were obtained, 62 students from 72 students met the minimum criteria with the percentage of mastery in the study at the third meeting was $86 \%$. Based on the assessed aspects, 45 of 72 students met good criteria in the aspect of content, 71 students met good criteria in content organizations, 72 students in vocabulary, 62 students in grammar and 62 students in spelling. This is supported by interviews with students. Students feel the use of film media as emotional lighters and groupings related to the storyline help them. Based on Figure 1 above, it can be seen the development of every aspect of narrative story writing.
Early skills that are good in aspects of organization of content, vocabulary and spelling. Three aspects of development have been improved in meeting 3 from the vocabulary aspect to $100 \%$ (72 students), organizational aspects contents $86 \%(62$ students), and spelling aspects $86 \%$ (62 students).

Initial abilities that are inadequate in aspects of content and grammar. But in its development there was an increase in the third meeting, the content aspect reached 63\% (45 students), and the grammatical aspect was $86 \%$ (62 students). The contents of ideas expressed by students are less creative, this is due to the ability of students to read less than the maximum. The development of the sentence in the narrative is also not optimal. This is understandable because it lacks adequate portions. This can be known during the study, students have difficulty developing sentences. The results of this study are in line with the research of Witdiatmoko A. (2016:2,082-2088) which examined the ability to write narratives using VCD Film cartoon media for Grade V students of SDN Setiadi. Aziz concluded that the process of learning narrative essays showed activeness, enthusiasm, and students' attention in learning, increased. The use of multisensory media and children's favor is indeed able to provide balanced brain stimulation.

\section{CONCLUSIONS}

Learning to write narratives based on balancing brain function begins with the stages of emotional reflection, clustering, expression, editing, reflection and ending display activities. Emotional lighters function to stimulate the discovery of ideas with class conditioning and student emotions. The use of multisensory media is carried out at the emotional reflection stage. The activity of an emotional institution is an activity that seeks to involve emotions in the search for ideas. The use of multisensory media is able to stimulate both the right brain and the left brain in a balanced manner. The use of multisensory media is able to summon student experience stored in its memory. The use of media in the emotional stage is expected to be able to find ideas. The discovery of this idea will later be expressed in sentences and developed in narrative essays. The use of picture media can produce students categorically mastery as many as 30 students, the use of concrete media objects 59 students, and the use of film media as many as 63 of the 72 students studied. The use of multisensory media is very important in implementing learning based on balancing

\section{ACKNOWLEDGMENT}

We would like to thank Causal Productions for permits to use and revise the template provided by Causal Productions. Original version of this template was provided by courtesy of Causal Productions (www.causalproductions.com). 


\section{REFERENCES}

Black, J. (2014). Model new media/video programs in arts education: Case study research. International Journal of Education \& the Arts, 15(6).

Chandler, D. (1995). The Act of Writing. Aberystwyth: University of Wales.

DePoter, B. \& Mike Hernacki. (2009). Quantum Learning. Bandung: Kaifa.

Given, B. K. (2002). Brain-Based Teaching: Merancang Kengiatan Belajar-Mengajar yang Melibatkan Otak Emosional, Sosial, Kognitif, Kinestetis, dan Reflektif. Bandung: Kaifa.

Graham, et.al. (2012). Teaching Elementary School Students to Be Effevtive Writers Washington, DC: National Center for Education Evaluation and Regional Assistance.

Hanson, A. (2009). Brain-Frendly Strategies for Developing Student Writing Skill Second Edition. USA: Corwin Press.

Hartati T, Darmawan D, Mulyasari E. (2013). Video Streaming for Creative Writing at International Elementary School. Journal of Education and Learning. Vol.7 (1) pp. 43-56.

Martin, S. J. (2010). "Skills Acquired Throughs Personal Narrative Writing Intruction". St. John Fisher College. Fhiser Digital Publication.New York: St. John Fisher College.

Nurgiyantoro, B. (2012). Penilaian Pembelajaran Bahasa Berbasis Kompetensi. Yogyakarta: BPFE.

Rivers, W. M. (1981). Teaching Foreign Language Skill. USA: The University of Chicago.

Schunk, D. H. (2012). Learning Theories an Education Prespective. (Terjemahan Teori-teori pembelajaran Prespektif Pendidikan Edisi Keenam oleh Eva Hamidah, Rahmat Fajar). Yogyakarta: Pustaka Pelajar.

Sousa, D. A. (2012). Bagaimana Otak Belajar. Jakarta: Indeks. Suparno dan Muhammad Yunus. 2008. Keterampilan Dasar Menulis. Jakarta: Universitas Terbuka.

Tompkins, G.E. (2008). Teaching Writing Balancing Process and Product. New Jersey: Pearsion Education.Inc.

Weiss. (2000). Brain Based Learning: The Wave of the Brain. Traning \& Development.

Witdiyatmoko, A. "Peningkatan Keterampilan Menulis Karangan Narasi dengan Menggunakan Media VSD Film Kartun Siswa Kelas IV SD" Jurnal Pendidikan Guru Sekolah Dasar Edisi Juni.

Yamac, A. and Ulusay, M. (2016). "The Effect of Digital Storytelling in Improving the Third Graders' Writing Skill" International Electronic Journal of Elementary Education, September 2016 Vol. 9 (1) 59-86 